\title{
Population structure of Czech cold-blooded breeds of horses
}

\author{
Luboš Vostrý1,2, Zuzana Čapková1, Josef Přiby|2,1, Barbora Hofmanová1, Hana Vostrá \\ Vydrová ${ }^{3}$ and Karel Mach ${ }^{1}$ \\ 'Faculty of Agrobiology, Food and Nature Resources, Czech University of Life Sciences, Prague, Czech Republic, \\ ${ }^{2}$ Institute of Animal Production, Prague - Uhríněves, Czech Republic, ${ }^{3}$ Faculty of Economics and Management, Czech \\ University of Life Sciences, Prague, Czech Republic
}

\begin{abstract}
In order to estimate effective population size, generation interval and the development of inbreeding coefficients $\left(F_{x}\right)$ in three original breeds of cold-blooded horses kept in the Czech Republic: Silesian Noriker (SN), Noriker (N) and Czech-Moravian Belgian horse (CMB) all animals of the particular breeds born from 1990 to 2007 were analysed. The average values of generation interval between parents and their offspring were: 8.53 in $\mathrm{SN}, 8.88$ in $\mathrm{N}$ and 8.56 in CMB. Average values of effective population size were estimated to be: 86.3 in SN, 162.3 in $\mathrm{N}$ and 104.4 in CMB. The average values of inbreeding coefficient were $3.13 \%$ in SN stallions and $3.39 \%$ in $\mathrm{SN}$ mares, in the $\mathrm{N}$ breed $1.76 \%$ and $1.26 \%$ and in the $\mathrm{CMB}$ breed $3.84 \%$ and $3.26 \%$ respectively. Overall averages of $\mathrm{F}_{\mathrm{x}}$ were: $3.23 \%, 1.51 \%$ and $3.55 \%$ for the breeds $\mathrm{SN}, \mathrm{N}$ and CMB. The average value of inbreeding coefficient $\mathrm{F}_{x}$ increased by $1.22 \%$ in $\mathrm{SN}$, by $0.35 \%$ in $\mathrm{N}$ and by $1.01 \%$ in $\mathrm{CMB}$, respectively. This may lead to a reduction in genetic variability. Reduction in genetic variability could be either controlled in cooperation with corresponding populations of cold-blooded breeds in other European countries or controlled by number of sires used in population.
\end{abstract}

Keywords: horse, cold blood, inbreeding rate, generation interval, effective population size

\section{Zusammenfassung}

\section{Populationsstruktur tschechischer Kaltblut-Pferderassen}

Ziel der Arbeit war die Schätzung der effektiven Populationsgröße, des Generationsintervalls und der Entwicklung des Inzuchtkoeffizienten $\left(\mathrm{F}_{\mathrm{x}}\right)$ für drei Kaltblut Pferderassen in der Tschechischen Republik: Schlesische Noriker (SN), Noriker (N) und Böhmisch-Mährische Belgier (CMB). Die Analyse erfolgte mit allen Tieren, welche zwischen 1990 und 2007 geboren wurden. Das Generationsintervall zwischen Eltern und ihren Nachkommen betrug bei SN 8,53, bei N 8,88 und bei CMB 8,56. Für die effektive Populationsgröße ergaben sich Schätzwerte von 86,3 für SN, 162,3 für N und 104,4 für CMB. Die durchschnittlichen Inzuchtkoeffizienten (\%) lagen bei 3,13 für Hengste bzw. 3,39 für Stuten, bei N 1,76 bzw. 1,26 und bei CMB 3,84 bzw. 3,26. Die durchschnittlichen Inzuchtkoeffizienten für die Rassen betrugen in der Reihenfolge SN, N, CMB 3,23, 1,51 und 3,55\%. In dem erfassten Zeitabschnitt 
erfolgte eine Zunahme des Inzuchtkoeffizienten bei SN, N, und CMB von 1,22, 0,35 und 1,01\%. Dies könnte zu einer Verringerung der genetischen Variabilität führen. Diese Reduzierung der genetischen Variabilität kann eingeschränkt werden durch eine Nutzung des Potenzials vergleichbarer Kaltblutpopulationen in anderen europäischen Ländern oder durch die Anzahl der eingesetzten Beschäler in den hier untersuchten Populationen.

Schlüsselwörter: Pferd, Kaltblut, Inzuchtrate, Generationsintervall, effektive Populationsgröße

\section{Introduction}

Small populations such as the three breeds of cold-blooded horses in the Czech Republic Silesian Noriker (SN), Noriker (N) and Czech-Moravian Belgian Horse (CMB) - bear the risk of inbreeding and reduction in genetic diversity with the population. The mating of related animals (inbreeding) was previously aimed at strengthening the required characteristics and traits in the population and at the concentration of appropriate genes in the population. Another aim was to increase offspring uniformity. However, it was observed at the same time that an increase in the inbreeding coefficient caused an increase in mortality, fertility and adaptability of farm animals (Falconer \& Mackay 1996). The objective of conservation breeding is to maintain genetic diversity in the population of farm animals. A reduction in genetic diversity is connected with the parameter of effective population size which is used to design the strategy for the conservation of endangered animal species (Bijma et al. 2001). The Food and Agriculture Organization (FAO) classifies breeds into different categories according to the type of endangerment, e.g. whether population size increases, decreases or remains stable.

The populations of cold-blooded horses in the Czech Republic are small sized, which has led to an increase in the population inbreeding coefficient of these breeds, especially in the 1990s when these populations were secluded from the import of genes from other populations. The increase in inbreeding coefficient may bring about undesirable inbreeding depression that is manifested in characteristics associated with fitness and reproduction and in other characteristics related.

The cold-blooded breeds Silesian Noriker, the Noriker and the Czech-Moravian Belgian Horse, along with Old Kladruber Horse and Hucul, belong to the group of endangered horse breeds in the Czech Republic. In the last approx. 120 years CMB has been formed in the Bohemian territory on the basis of imports of mainly original Belgian stallions and Walloon stallions to a lesser extent. Breeding goal of $\mathrm{CMB}$ is a horse with a medium square frame and earlier maturity. Silesian Noriker has originated in the last approx. 100 years from imports of original Noriker stallions and Bavarian cold-blooded stallions. Breeding goal of SN is a horse with a longer frame and later maturity. Noriker breed was formerly used for the formation of SN breed and has been kept in the Bohemian territory for approx. 150 years. The two N breeds were further separated geographically to a greater extent. Breeding goal of $\mathrm{N}$ is a horse with a medium-sized frame and earlier maturity.

The objective of the present paper was the analysis of development of the inbreeding coefficient, of effective population size and of generation interval in the populations of coldblooded horses in the Czech Republic. 


\section{Material and methods}

Inbreeding coefficients $\left(\mathrm{F}_{\mathrm{x}}\right)$ were estimated for all horses regardless of their sex on the basis of complete pedigrees, i.e. pedigrees used comprised all generations reaching back to the founders of the particular breeds - more than 8 generations of ancestors in each horse altogether 50845 horses. Horses without known ancestors were included as unrelated animals with zero inbreeding coefficient $\left(\mathrm{F}_{x}=0\right)$. Data sets were provided by the Horse Breeders Association of the Czech Republic (http://www.aschk.cz). The coefficient $F_{x}$ was estimated as a coancestry coefficient (Falconer \& Mackay 1996) using the INBREED procedure of SAS package (SAS 2005):

$$
F_{x}=f_{W Z}=0.25\left(f_{A C}+f_{A D}+f_{B C}+f_{B D}\right)
$$

where $f$ is the coancestry coefficient between two horses, e.g. $W$ and $Z$ when $A$ and $B$ represent the parents of horse $W$ while $C$ and $D$ are the parents of horse $Z$.

The estimated inbreeding coefficients were used to determine the expected change in inbreeding coefficient over a year $\left(\Delta F_{y}\right)$ and to estimate the effective population size $\left(N_{e}\right)$ (Falconer \& Mackay 1996).

The effective population size $\left(N_{e}\right)$ was estimated from the quotient of a change in inbreeding coefficient per generation $(\Delta F)$, calculated as the product of a change in inbreeding coefficient per year $\left(\Delta F_{y}\right)$ and the generation interval (L) (Sørensen et al. 2005):

$$
N_{e}=\frac{1}{2 \Delta F_{y} L}
$$

Generation interval $(L)$ comprised four real ways of gene transfer: from sire to son $\left(L_{m m}\right)$, from sire to daughter $\left(L_{m f}\right)$, from dam to son $\left(L_{f m}\right)$ and from dam to daughter $\left(L_{f f}\right)$ (Nomura et al. 2001):

$$
L=\frac{L_{m m}+L_{m f}+L_{f m}+L_{f f}}{4}
$$

The analysis of the studied populations was done by a comparison of animals born in 1990 and 2007.

\section{Results and discussion}

\section{Breed development}

Tables 1 to 3 show the structure and population size of the particular breeds. Population sizes have been gradually growing since 1993 , mainly due to an increase in the number of stallions which has risen from the original 3 to 5 to 34 to 39 stallions. The increasing number of stallions was caused by including more stallions into the breeding scheme. On the other hand, while the numbers of mares remained relatively similar within the period of observation for the breeds $\mathrm{SN}$ and $\mathrm{CMB}$, mare numbers have been reduced to a half in the $\mathrm{N}$ breed. 
Table 1

Average inbreeding coefficients of SN within stallions and mares in 1990 and 2007

\begin{tabular}{lccccccc}
\hline Year & \multicolumn{2}{c}{1990} & \multicolumn{2}{c}{2007} & Difference & Min* $^{*}$ & Max* $^{*}$ \\
Sex & $\mathrm{n}$ & Average $\mathrm{F}_{\mathrm{x}}$ & $\mathrm{n}$ & Average $\mathrm{F}_{\mathrm{x}}$ & $\mathrm{F}_{\mathrm{x}}$ & $\mathrm{F}_{\mathrm{x}}$ & $\mathrm{F}_{\mathrm{x}}$ \\
\hline Stallions & 3 & 0.0314 & 39 & 0.0313 & -0.0001 & 0.00 & 0.0870 \\
Mares & 28 & 0.0189 & 26 & 0.0339 & 0.0150 & 0.00 & 0.1155 \\
Total & 33 & 0.0201 & 65 & 0.0323 & 0.0122 & 0.00 & 0.1155 \\
\hline
\end{tabular}

*refer to values in 2007

Table 2

Average inbreeding coefficients of N within stallions and mares in 1990 and 2007

\begin{tabular}{lccccccc}
\hline Year & \multicolumn{2}{c}{1990} & \multicolumn{2}{c}{2007} & Difference & Min* $^{*}$ & Max* $^{*}$ \\
Sex & $\mathrm{n}$ & Average $\mathrm{F}_{\mathrm{x}}$ & $\mathrm{n}$ & Average $\mathrm{F}_{\mathrm{x}}$ & $\mathrm{F}_{\mathrm{x}}$ & $\mathrm{F}_{\mathrm{x}}$ & $\mathrm{F}_{\mathrm{x}}$ \\
\hline Stallions & 5 & 0.0160 & 34 & 0.0176 & 0.0016 & 0.00 & 0.1302 \\
Mares & 65 & 0.0113 & 35 & 0.0126 & 0.0013 & 0.00 & 0.1302 \\
Total & 70 & 0.0116 & 69 & 0.0151 & 0.0035 & 0.00 & 0.1302 \\
\hline
\end{tabular}

${ }^{*}$ refer to values in 2007

Table 3

Average inbreeding coefficients of CMB within stallions and mares in 1990 and 2007

\begin{tabular}{lccccccc}
\hline Year & \multicolumn{2}{c}{1990} & \multicolumn{2}{c}{2007} & Difference & Min* $^{*}$ & Max* $^{*}$ \\
Sex & $\mathrm{n}$ & Average $\mathrm{F}_{\mathrm{x}}$ & $\mathrm{n}$ & Average $\mathrm{F}_{\mathrm{x}}$ & $\mathrm{F}_{\mathrm{x}}$ & $\mathrm{F}_{\mathrm{x}}$ & $\mathrm{F}_{\mathrm{x}}$ \\
\hline Stallions & 3 & 0.0208 & 55 & 0.0384 & 0.0176 & 0.00 & 0.1523 \\
Mares & 58 & 0.0256 & 52 & 0.0326 & 0.0070 & 0.00 & 0.0898 \\
Total & 61 & 0.0254 & 107 & 0.0355 & 0.0101 & 0.00 & 0.1523 \\
\hline
\end{tabular}

*refer to values in 2007

\section{Inbreeding}

The values of inbreeding coefficient were as follows: $F_{x}=0$ for $23.68 \%$ of horses, $F_{x}$ values $0<F_{x}<0.0625$ for $70.01 \%$ of horses, $F_{x}$ values $0.0625<F_{x}<0.125$ for $5.79 \%$ of horses and $F_{x}$ values $>0.125$ for $0.52 \%$ of horses. The first two groups $\left(F_{x}<0.0625\right)$ comprised $93.69 \%$ of all horses. Similar distributions of $\mathrm{F}_{\mathrm{x}}$ values were shown in other farm animals (Bezdíček et al. 2008, Maiwashe et al. 2008, Biedermann et al. 2009, Köck et al. 2009).

Figure 1 illustrates the development of the mean of $F_{x}$ values according to year of birth in horses of the particular breeds in the period 1990 to 2007. The lowest $F_{x}$ value was determined for all breeds of horses born in 1994 and 1999. A steep increase was observed between years 1994 and 1999. Since 1999, there has been an increase of different intensity in $F_{x}$ in the breeds studied. The general increase in $F_{x}$ values since 1994 was caused by the closing of populations of cold-blooded horses in the Czech Republic in that year against the immigration of genes of the other phylogenetically related horses populations. The peak of $F_{x}$ in the SN breed for horses born in 1995 compared to the other breeds resulted from the low number of horses of this breed which, in addition, also had a higher average $F_{x}$ value. Different values of average inbreeding coefficients among breeds determined in 2007 were caused by different breeding methods used in these breeds. Tables 1 to 3 also document an 
increase in inbreeding coefficient in the particular breeds during the period of observation (1990-2007). The largest change was found in the CMB breed and the smallest in the N breed. Stallions of the SN breeds had the lowest increase in the $F_{x}$ coefficient and stallions of CMB had the highest similar to the values for the whole population. In mares the lowest change was observed for the CMB breed while the highest change was recorded for the SN breed. As documented by the tables, the increase in the $F_{x}$ coefficient of SN horses born in 19902007 was caused by an increase in the average value of $F_{x}$ coefficients in mares whereas in stallions the average $F_{x}$ coefficient did not changed. In the CMB breed the average value of $F_{x}$ in $C M B$ breed increased as a result of its increase in stallions while in mares the average coefficient $F_{x}$ showed a smaller change. In the $\mathrm{N}$ breed the increase in $\mathrm{F}_{\mathrm{x}}$ was similar in both sexes. Similar values of $F_{x}$ were estimated by Jakubec et al. (2009) in Old Kladrub horses and by Wolc \& Balińska (2010) in the Polish Konik population. Sierszchulski et al. (2005) found average values of $F_{x}=0.88 \%$ in the Polish Arab horse. The rate of $F_{x}$ is of a great importance for the future development of any population. It is considered the decisive measure for estimation of the degree of endangerment within a population. High rates of inbreeding are linked to a progressive loss of genetic variability. The trends of inbreeding found in the present study are highly dependent on the use of individuals of Czech cold-blooded breeds for reproduction. In the year 1990 only 3 to 5 stallions were used for reproduction in the dependence on the breed. As a consequence in the years 2007 already 34 to 55 stallions were used for reproduction in the dependence on the breed. This corresponds with the increase of $F_{x}$ in 1990 and $F_{x}$ stagnation after 2005.

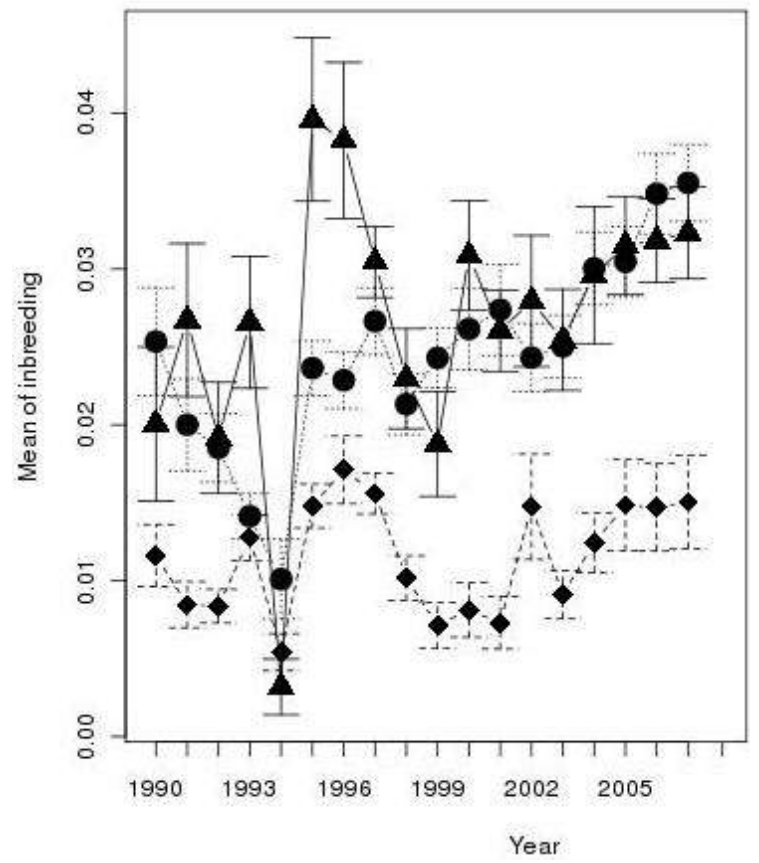

Figure 1

Development of the average value of inbreeding coefficient by the years of birth

( $\boldsymbol{\Delta}$ - Silesian Noriker, $\boldsymbol{\square}$ - Noriker and - Czech-Moravian Belgian horse) 


\section{Generation interval}

Table 4 shows the values of generation interval $(\mathrm{L})$, expressed as the average age of a horse at the time of birth of its offspring (Falconer \& Mackay 1996), over the whole period of observation and over the period from 1990 to 2007, separately for both sexes. Average generation interval was 8.53 years in SN, 8.88 in N and 8.56 years in CMB. Generation interval of horses born in 1990-2007 and their sires was 9.47 years in SN, 9.62 years in N and 9.17 years in CMB. The values of dams were 8.37 years in SN, 8.57 in N and 8.44 years in CMB. Tables 4 and 5 document that in horses born before 1990 the value of $L$ was lower by approx. 0.5 a year compared to animals born after 1990. CMB breed was the only exception in which a higher value of $L$ was estimated in horses born before 1990. It was caused by mating in all breeds at a younger age by 1990 . The birth of offspring was recorded already at 3 years of age in a higher number of horses born before 1990. Table 5 shows that in most cases the interval between the parent and the son is shorter than between the parent and the daughter. SN breed was the exception when the value of $L$ was higher in the segment between sire and son compared to the segment between sire and daughter. Similar values were estimated by Druml et al. (2009) in the Austrian Noriker breed ( $L=7.9)$ and by Poncet et al. (2006) in the Franches-Montagnes breed ( $L=8.4)$. Slightly higher values were reported by Valera et al. (2005) in Carthusian horses. Compared to the other breeds of farm animals, horses reach a higher generation interval. The longer generation interval is typical for the horse breeding. These higher values of $L$ are caused by older age at birth of the first offspring (4 years in males and females) and by older age at birth of the last offspring (from 19 to 29.6 years in males and from 19 to 23 years in females), depending on the breed. The values determined in this study correspond to the above mentioned data when the youngest age at birth of the offspring was 4 years. Within small populations that primarily have the aim of breed conservation, long generation intervals are advantageous in order to minimize the increase of inbreeding per unit of time. On the other hand, the time span is longer before an increase in inbreeding rate because the low numbers of stallions and breeding mares used can be observed (Hamann \& Distl 2008). However, the prolonging of the generation intervals in Czech cold-blooded breeds is not sufficient to compensate for the small number of individuals forming the breed. Nevertheless, markedly higher values of $L$ were determined in English Thoroughbred ( $L=11.2$ for males and $L=9.7$ for females) (Thiruvenkadan et al. 2009). A shorter generation interval is typical of cold-blooded horses. The main reason is that they need not to undergo long training and athletic performance. The higher value of $\mathrm{L}$ in warm-blooded horses is also due to the fact that outstanding sires with a high number of offspring maintain their athletic ability for a longer time and are included in reproduction at older age.

Table 4

Generation interval $(\mathrm{L})$ and effective population size $\left(\mathrm{N}_{\mathrm{e}}\right)$ - Overall

\begin{tabular}{lcccccc}
\hline & & \multicolumn{3}{c}{ Generation interval } & & \\
& Overall & until 1990 & Overall & $\begin{array}{c}\text { 1990-2007 } \\
\text { Stallions }\end{array}$ & Mares & \\
\hline SN & 8.52 & 8.50 & 8.53 & 9.47 & 8.37 & 43.14 \\
N & 8.71 & 8.37 & 8.88 & 9.62 & 8.57 & 79.11 \\
CMB & 8.69 & 8.97 & 8.56 & 9.17 & 8.44 & 52.21 \\
\hline
\end{tabular}

*includes all living individuals able of reproduction 
Table 5

Estimated generation interval (years) for different selection paths

\begin{tabular}{lcccccc}
\hline & & Sires & & \multicolumn{3}{c}{ Dams } \\
& Son & Daughter & Range & Son & Daughter & Range \\
\hline SN & 10.08 & 9.79 & from 4 to 29.6 & 8.46 & 8.80 & from 4 to 23 \\
N & 9.19 & 9.87 & from 4 to 29.5 & 8.88 & 9.02 & from 4 to 19 \\
CMB & 8.93 & 9.35 & from 4 to 19 & 8.42 & 8.99 & from 4 to 22 \\
\hline
\end{tabular}

\section{Effective population size}

Table 4 illustrates effective population size $\left(\mathrm{N}_{\mathrm{e}}\right)$ derived from the increase in the average value of inbreeding coefficient per generation (Falconer \& Mackay 1996). The lowest value of $\mathrm{N}_{\mathrm{e}}$ was estimated in SN (43.14) while the highest value of $\mathrm{N}_{\mathrm{e}}$ was found out in $\mathrm{N}$ breed (79.11). CMB breed showed the value $\mathrm{N}_{e}=52.21$. The numbers of founders in the total reference population were 98, 139, 168 (SN, N, CMB respectively), but the effective numbers of founders were only $43.14,79.11$ and 52.21 (SN, N, CMB respectively) animals. Hence, it becomes evident that some founders could be used more intensively than others, which is always critical in terms of loss of genetic diversity. Similar values of $\mathrm{N}_{\mathrm{e}}$ were determined in breeds of German cold-blooded horses $\mathrm{N}_{\mathrm{e}}=81.4-332.2$ (Aberle 2003) and in Austrian Noriker $\mathrm{N}_{\mathrm{e}}=$ from 119 to 195 (Druml et al. 2009). Jakubec et al. (2006) estimated higher values of $N_{e}$ (140.3) in the Old Kladruber horse. A comparison of the values of $\mathrm{N}_{e}$ indicates that the analysed breeds of cold-blooded horses belong to the group of endangered populations. Meuwissen \& Woolliams (1994) revealed a fundamental relationship between the effective population size and genetic variances of fitness traits. These authors concluded that the critical size for $\mathrm{N}_{\mathrm{e}^{\prime}}$ i.e. the size below which the fitness of the population decreases, is between 50 and 100 .

The results document an increase in the coefficient of inbreeding that has been observed in original cold-blooded horses in the Czech Republic in the last years. Inbreeding coefficient in the original cold-blooded horses in the Czech Republic can be considered as low. The increase in inbreeding coefficient has been caused by small populations of the particular breeds. Compared with other breeds like the Andalusian, the Lipizzan or the Old Kladruber horse, this level can be considered as low. On the contrary, inbreeding in the Austrian Noriker draught horse is at a same level (1.2\% - Druml et al. 2009). The objective of further breeding work should be a gradual increase in the population size of breeds using a planed mating combination of parents in order to avoid an increase in the relationship between horses and a decrease in genetic variability. Other possibilities could be measures such as common breeding schemes in cooperation with corresponding populations in other European countries or controlled by number of sires used in population. All these measures might also help in a reduction of costs for keeping the numerous small populations of similar genetic background because the taxpayers want to know good reasons when they have to give their money for these populations. 


\section{Acknowledgements}

This work was supported by the Ministry of Education, Youth and Sports of the Czech Republic (Project No. MSM 6046070901) and by the Ministry of Agriculture of the Czech Republic (Project No. MZE 0002701404). We will gratefully acknowledge the helpful comments of any reviewers.

\section{References}

Aberle K, Wrede J, Distl O (2003) Analysis of the population structure of the Black Forest Draught Horse. Berl Münch Tierärztl Wochenschr 116, 333-339

Bezdíček J, Šubrt J, Filipčík R (2008) The effect of inbreeding on milk traits in Holstein cattle in the Czech Republic. Arch Tierz 51, 415-425

Biedermann G, Hecht W, Fandrey E, Rudolph H, Froelich K (2009) Population genetic analysis of White Park Cattle in Germany. Arch Tierz 52, 561-573

Bijma P, Van Arendonk JAM, Woolliams JA (2001) Predicting rate of inbreeding for livestock improvement schemes. J Anim Sci 79, 840-853

Druml T, Baumung R, Sölkner J (2009) Pedigree analysis in the Austrian Noriker draught horse: genetic diversity and the impact of breeding for coat colour on population structure. J Anim Breed Genet 126, 348-356

Falconer DS, Mackay TFC (1996) Introduction into quantitative genetics. Longman House, Harlow, Essex, UK

Hamann H, Distl O (2008) Genetic variability in Hanoverian warmblood horses using pedigree analysis. J Anim Sci 86, 1503-1513

Jakubec V, Vostrý L, Schlote W, Majzlík I, Mach K (2009) Selection in the genetic resource: genetic variation of the linear described type traits in the Old Kladrub horse. Arch Tierz 52, 343-355

Köck A, Fürst-Waltl B, Baumung R (2009) Effects of inbreeding on number of piglets born total, born alive and weaned in Austrian Large White and Landrace pigs. Arch Tierz 52, 51-64

Maiwashe A, Nephawe KA, Theron HE (2008) Estimates of genetic parameters and effect of inbreeding on milk yield and composition in South African Jersey cows. S Afr J Anim Sci 38, 119-125

Meuwissen THE, Woolliams JA (1994). Effective sizes of livestock populations to prevet a decline in fitness. Theor Appl Genet 89, 1019-1026

Nomura T, Honda T, Mukai F (2001) Inbreeding and effective population size of Japanese Black cattle. J Anim Sci 79, 366-370

Poncet PA, Pfister W, Muntwyler J, Glowatzki-Mullis ML, Gaillard C (2006) Analysis of pedigree and conformation data to explain genetic variability of the horse breed Franches-Montagnes. J Anim Breed Genet 123, 114-121

SAS (2005) SAS User Guide 9.1, Cary, NC, USA

Sierszchulski J, Helak M, Wolc A, Szwaczkowski T, Schlote W (2005) Inbreeding rate and its effect on three body conformation traits in Arab mares. Anim Sci Pap Rep 23, 51-59

Sørensen AC, Sørensen MK, Berg P (2005) Inbreeding in Danish Dairy Cattle Breeds. J Dairy Sci 88, 1865-1872

Thiruvenkadan AK, Kandasamy N, Panneerselvam S (2009) Inheritance of racing performance of Thoroughbred horses. Liv Prod 121, 308-326 
Valera M, Molina A, Gutierez JP, Gomez J, Goyache F (2005) Pedigree analysis in the Andalusian horse: population structure, genetic variability and influence of the Carthusian strain. Liv Prod Sci 95, 57-66

Wolc A, Balińska K (2010) Inbreeding effects on exterior traits in Polish konik horses. Arch Tierz 53, 1-8

Received 21 June 2010, accepted 8 November 2010.

Corresponding author:

Luboš Vostrý

email: vostry@af.czu.cz

Czech University of Life Science, Kamýcká 129, 16521 Prague 6-Suchdol, Czech Republic 